https://doi.org/10.48009/2_iis_2010_83-87

\title{
USING TWITTER TO DELIVER CLASS ANNOUNCEMENTS: THE GOOD, THE BAD, AND THE UGLY
}

\author{
Kimberly W. Bartholomew, Utah Valley University, barthoki@uvu.edu \\ John E. Anderson, Utah Valley University, janderson@uvu.edu
}

\begin{abstract}
We describe the use of Twitter to deliver class announcements as a way to enhance social presence in two online courses by increasing both the immediacy and frequency of contact between instructor and student. We found that most students were ambivalent to using Twitter in this way and only about $14 \%$ would follow the tweet.
\end{abstract}

Keywords: Social Presence, Online Learning, Twitter, Social Interaction, Microblogging, Student Engagement

\section{BACKGROUND}

The collection of technologies termed "social computing," "Web 2.0," and "online communities" includes blogs, wikis, social bookmarking, peer-topeer networks, open source communities, photo and video sharing communities illustrate a fundamental shift in communication, computing, collaboration, and commerce. These technologies move beyond a channel for communication and commerce to an environment for organizing human endeavor, facilitating social interactions, and empowering creativity.(Parameswaran \& Whinston 2007) This convergence of social and technological networks has led to changes in styles of communication and the ability to study the evolution of social networks as the technology has eased the collection of data concerning these social processes. (Kleinberg, 2008) Social networking is becoming the norm with the user base of Facebook.com exceeding 400 billion. (Palavia \& Pancaro, 2010) Twitter.com has approximately 106 million users. (Huffington, 2010)

Efforts to examine the appropriateness of Web 2.0, social networking, microblogging and other trends for online education at the tertiary level are underway at many institutions. A new generation of college students known as Generation $\mathrm{Y}$ has created a misunderstood and mysterious target market for academic programs. Beyond the walls of the classroom, these students frequently participate in a myriad of online knowledge creating communities that are open to all and are supported by freely available social software tools. Modern tech-savvy students have an expectation that these tools they so adeptly use in their private lives should also be utilized in academic settings (Kryzanek, 2005).

The question as to what technologies should be leveraged in collegiate courses needs to be answered. Choosing a technological solution for technologies' sake without regard to how it will fit in the teaching pedagogy was referred to as techno-centrism by Papert (1990) and unfortunately is the frequent result of may educational initiatives. Ineffective e-learning is often the result of too much enthusiasm or inexperience on the part of an instructor or decisionmaker (Nichols, 2007).

An important step in determining if a technology is appropriate is to identify the target audience and key characteristics of that audience. What are the expectations Generation $\mathrm{Y}$ students have for elearning systems? First and foremost, students expect real-time, 24/7 access to their courses, online resources, and often to online help (Prensky, 2005). Gen Y students want and need to feel that they are part of a community. They object when email, discussion forums, wikis and blogs are not part of the wider world Internet (Green, Facer, Rudd, Dillion, \& Humphreys, 2005). With the advent of 3rd generation (3G) phones like the iPhone which support increased bandwidth and Internet connectivity, interested educators are seeking to upgrade their own digital communication skills and develop appropriate pedagogies, and new practices that provide a best-fit with this new capability (Wagner, 2005).

\section{INTRODUCTION}

In the past we have taught two information systems courses online using the structure and function of our campus-wide learning management system (LMS) Blackboard Vista. While this has been adequate for learning activities such as drop boxes for assignments and gradebooks, the instructors desired to increase the collaborative and social presence aspects of the course by experimenting with Twitter (2010), a Web 2.0 microblogging tool. In this paper we describe the results of introducing Twitter as a way to deliver class announcements. 


\section{Always Having To Log In}

While LMS such as Blackboard Vista are adequate for many learning activities, there are always student complaints about having to $\log$ in to access information. This prompted the instructors to wonder if there was a way to give students information related to the course outside of the LMS that would at the same time improve the course. A second problem to which the instructors have been seeking solutions was trying to give an online course more the social "feel" of a face-to-face course.

\section{Twitter and Social Presence}

Twitter is one possible solution to the problems of giving students course related information outside of the LMS and enhancing the social aspects of the course.

Social presence is a construct well established in the online education literature to describe the degree of salience (i.e., the quality of "being there") between communicators (Short, Williams, \& Christie, 1976; Garrison, Anderson, \& Archer, 2000; Lowenthal, 2009). Dunlap and Lowenthal (2009) have noted that because students and faculty have to login and navigate to several different locations in an LMS there is a loss of the just-in-time or real-time information flow natural to face-to-face courses. They used Twitter as a way to enhance social presence in their online course. Twitter allows people, in 140 characters or less, to share ideas, ask questions, and collaborate in essentially real-time. Twitter members post contributions by way of the Twitter website, mobile phones, email, and instant messaging. Twitter members then choose which other member's Twitter feeds they would like to follow.

Several university faculty have used Twitter as a course communication tool (Parry, 2008; Sweetser, 2008; Keefer, 2008; van den Broek, 2009; Sendall, Ceccucci, \& Peslak, 2008, and Dunlap \& Lowenthal, 2009) to enhance collaboration. Wankel (2009) suggested that Twitter be used to announce events, remind students, and provide encouragement.

\section{Motivation for the Use of Twitter}

A motivation for including the use of Twitter in these online courses was to determine the level of diffusion for this innovation among business and technology students at our institution. Our thinking was that most students had access to $3 \mathrm{G}$ phones and preferred text messaging over other means of communication. Could class announcements, alerts, and reminders be pushed more effectively to students through the means of microblogs than through traditional email within a LMS? This was the question posed by this experiment.

\section{Twitter to Deliver Course Announcements}

We decided to use Twitter to enhance the social presence of our course by increasing both the immediacy and frequency of contact between instructor and student. We used Twitter to deliver course announcements to the online sections of the INFO 2450 Web Application Design and INFO 3120 Principles of Information Systems: A Managerial Perspective during the Fall 2009 semester.

The instructor also made use of a Twitter account to provide class announcements. The tweets were displayed in the right column on each page a class blog where they were visible to all students in the class. Students could sign-up to follow the twitter announcements so that they could then see them on their mobile devices. A link to the twitter class announcements was also provided to all students as a main navigation menu option in Blackboard. Each announcement was also emailed to students using Blackboard mail.

\section{RESEARCH METHODOLOGY}

Our research centered upon the following exploratory research question: Can Twitter (micro-blogging) enhance class communication be delivering announcements?

A voluntary survey was created in which students were asked to provide answers and comments about their use of Twitter in the course. The questions were derived from an attempt to fulfill accreditation requirements for course improvement. The multipart question asked was:

1. How do you feel about having our class announcements in Twitter? Select all that apply ...

2. I like that I can access them publicly

3. I like having these announcements on the class blog

4. I currently follow this tweet on my phone or computer

5. If I knew how, I would follow this tweet on my phone or computer

6. I do not read these announcements

7. I would just rather get email announcements 
8. I don't want announcements or email updates

The researchers analyzed the responses with descriptive statistics and qualitative comment categorization.

\section{FINDINGS \& DISCUSSION}

The response rate for the survey was surprisingly good, 40 out of $54(74 \%)$ and 25 out of $32(78 \%)$ students took the survey. A table and graph of the responses is seen below in Table 1 and Figure 1 below.

Table 1: Twitter use results

\begin{tabular}{|l|c|c|c|c|}
\hline \multicolumn{2}{|l|}{ How do you feel about having our class announcements in Twitter? } & \multicolumn{2}{l|}{} \\
\hline & $\begin{array}{c}\text { INFO } \\
2450 \\
\text { Qeb- } \\
\text { Question }\end{array}$ & $\begin{array}{l}\text { Dev } \\
3120 \\
\text { MIS }\end{array}$ \\
\hline 1) I like that I can access them publicly & 8 & $15 \%$ & 6 & $19 \%$ \\
\hline 2) I like having these announcements on the blog & 7 & $13 \%$ & 3 & $9 \%$ \\
\hline 3) I currently follow this tweet on my phone or computer & 2 & $4 \%$ & 1 & $3 \%$ \\
\hline 4) If I knew how, I would follow this tweet on my phone or computer & 2 & $4 \%$ & 5 & $16 \%$ \\
\hline 5) I do not read these announcements & 17 & $31 \%$ & 16 & $50 \%$ \\
\hline 6) I would just rather get email announcements & 23 & $43 \%$ & 11 & $34 \%$ \\
\hline 7) I don't want announcements or email updates & 1 & $2 \%$ & 0 & $0 \%$ \\
\hline
\end{tabular}

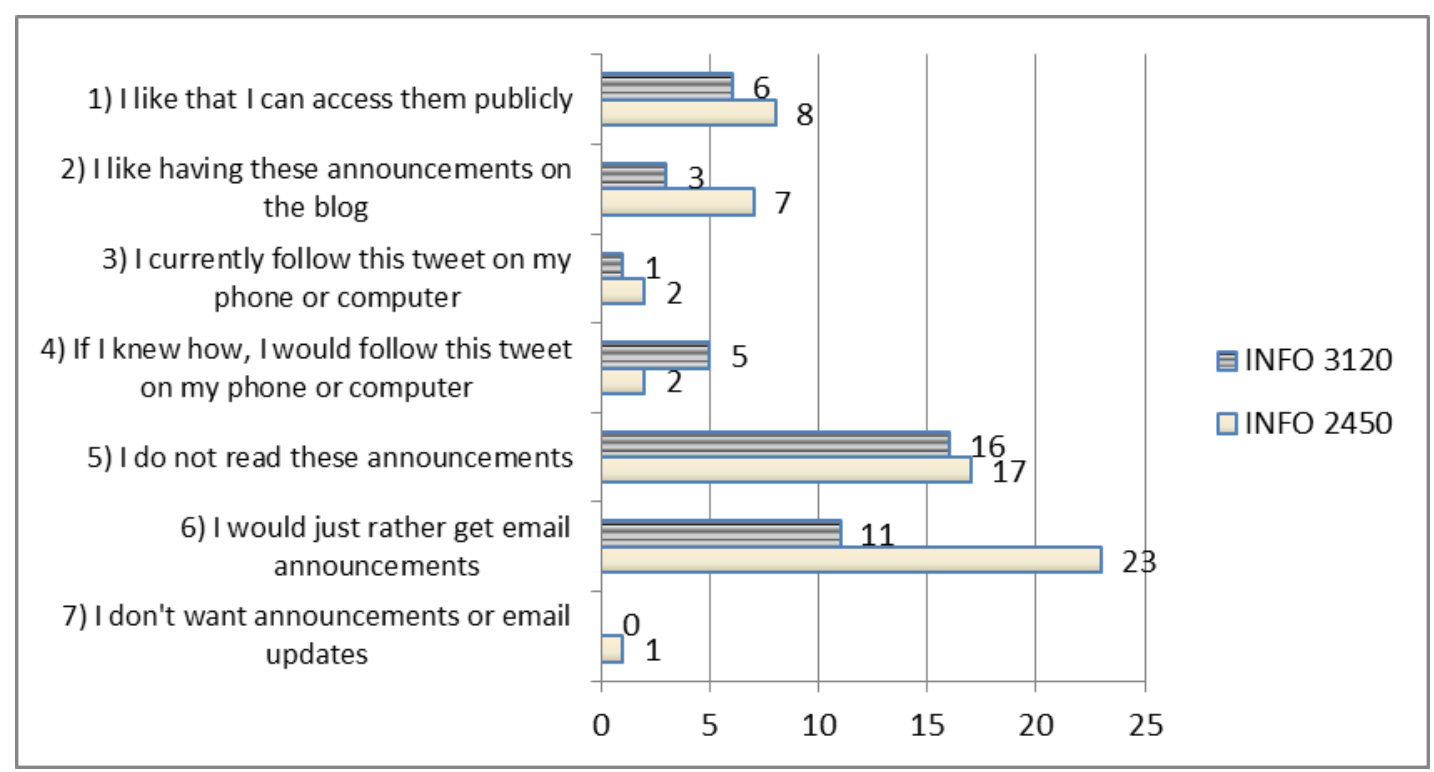

Figure 1. Twitter use results in graphical form

\section{The Good}

On average, about $17 \%$ liked the public Twitter access. About $11 \%$ like having the Twitter announcement feed on the public blog.
Student comments:

"I think it is great to use all of the technology that we have available." 
"I'm fairly new to Twitter and would like to know more of the benefits of using Twitter in the workplace."

"I think they are very useful and it is much easier to receive class updates than having to $\log$ in to blackboard. It gives more incentive to take the time to see what updates there are."

\section{The Bad}

Most students were ambivalent about the use of Twitter for class announcements. On average, about $40 \%$ said they do not read the twitter announcements. About 39\% said they would rather get announcements on email. Interestingly, this was the only question that had a different response between the 2 classes. Surprisingly, of more tech-savvy INFO 2450 students, $43 \%$ would rather have email updates than Twitter updates.

\section{Student Comments:}

"I don't follow twitter at all so it is better for me just to receive emails or post it on blackboard."

"I hate twitter too. Useless. There is already an announcement feature on blackboard. Use that. I have never been in a class where I have to go to so many different websites just to find out what I'm supposed to do.”

"Not a Tweeter. Never considered myself too old for technology, but I see this as a major waste of time. Maybe I am old!?”

\section{The Ugly}

Only 3 students, that is $4 \%$, choose to follow the announcement tweet on their mobile devices. Only $10 \%$ more would follow the tweet if they knew how. Thus, only about $14 \%$ would follow the tweet. Student comments:

"I get on and read them, but still have no idea how to fully utilize twitter."

"I haven't really noticed where they pop up. I think they are on the right hand side of the blog, but not really sure if the source is Twitter."

It surprised the researchers that only $17 \%$ of students like the idea and only between 4 - 14\% of students will follow it given that Twitter is a cutting-edge popular technology. Many think Twitter is a waste of time. Some don`t know how to use Twitter. Many favor using email or Blackboard for class announcements over Twitter. Perhaps this use of Twitter is too new, or Twitter adoption is too small. Although Twitter is used in many professional settings, perhaps students don't like school interfering with a communication stream they deem as more personal.

In response to accreditation requirements, students taking both the MIS and Web Design courses are asked to become familiar with skills and technologies they will encounter in their professional lives. Twitter is rapidly becoming a common marketing and communication tool for business (Gaudin, 2009). While students at this time may not feel the need to use Twitter for two-way communication with an instructor, the option will continue to be made available for those who want course alerts available anytime/anywhere.

\section{Questions for Future Research}

Is it worth creating and updating a Twitter tweet for the announcements of class if only $17 \%$ of students like the idea and only between $4-14 \%$ of students will follow it?

Can technologies like twitter be successfully used for just-in-time communication between students and teachers, or is this technology still too new?

If students were trained on the use of twitter, would micro-blogging be more successful for alerts and announcements?

Do students want to separate their personal lives from their academic lives? Do they see twitter alerts as an intrusion rather than a service?

Should teachers be available $24 / 7$ a day to elicit discussion?

\section{CONCLUSIONS}

The experiment to echo class announcements using twitter and provide an RSS feed to the tweets both inside Blackboard and in the class blog was ambivalent at best. As you can see from student comments, there was a wide range of feedback from positive to very negative. Almost no effort was made by the instructor to educate students on the use of twitter because the assumption was this tool was already well known to them. This may be one reason for the lack of adoption of this technology in these courses. While the RSS feed was placed in 
Blackboard in the course menu, students saw it as a burden to view and use and so tended to ignore this feature.

\section{REFERENCES}

1. Dunlap, J., \& Lowenthal, P. (2009)

Tweeting the Night Away: Using Twittr to Enhance Social Presence. Journal of Information Systems Education, 20(2), 129136

2. Gaudin, S. (2009, November) Business use of Twitter, Facebook exploding. Computerworld. Retrieved July, 19, 2010 from http://www.reuters.com/article/idUS118563 159020091110

3. Garrison, D., Anderson, T, and Archer, W., (2000) Critical Inquiry in a Text-based Environment: Computer Conferencing in Higher Education. The Internet and Higher Education, 2(2-3), 87-105

4. Green, H., Facer, K., Rudd, T., Dillion, P., \& Humphreys, P. (2005) Personalization and Digital Technologies. FutureLab. Retrieved April 11, 2010, from http://www.futurelab.org.uk/research/person alisation.htm

5. Twitter User Statistics Revealed. (April 2010) The Huffington Post accessed July 2010 http://www.huffingtonpost.com/2010/04/14/ twitter-user-statistics-r_n_537992.html

6. Keefer, J. (2008, March) How to use Twitter in Higher Education. Retrieved April 1, 2008, from http://silenceandvoice.com/archives/2008/03 /31/how-touse-twitter-in-higher-education/

7. Kleinberg, J. (2008, Nov) The Convergence of Social and Technological Networks. Communications of the ACM, 51(11), 66-72

8. Kryzanek, M. (2005) Anxieties Define Generation Y. The Boston Globe, The New York Times Company, December 8. Retrieved April 11, 2010 from http://www.boston.com/news/local/articles/2 005/12/08/anxieties_define_generation_y/

9. Lowenthal, P. (2009) "Social Presence," in Encyclopedia of Bistance and Online Learning, 2nd Edition, P. Rogers, G. Berg, J. Boettcher, C. Howard, L. Justice, and K Schenk (eds.), IGI Global, Hershey, PA, 1900-1906
10. Nichols, M. (2007) E-Primer: E-Learning in Context. Bible College of New Zealand. Retrieved April 11, 2010, from http://akoaotearoa.ac.nz/download/ng/file/gr oup-661/n877-1---e-learning-in-context.pdf

11. Palvia, S., \& Pancaro, R. (2010) Promises and Perils of Internet based Networking. Journal of Global Information Technology Management, 13(3), 1-9

12. Papert, S. (1990) A Critique of Technocentrism in Thinking about the School of the Future. Retrieved April 11, 2010 from, http://www.papert.org/articles/ACritiqueofT echnocentrism.html

13. Parameswaran, M., \& Whinston, A. (2007) Social Computing: An Overview. Communications of the Assoiciation of Information Systems, 19, 762-780

14. Parry, B. (2008b, February) "Teaching With Twitter." The Chronicle of Higher Education. Retrieved March 1, 2008, from http : //chronicle. com/media/video/v54/i2 5/twitter/

15. Prensky, M. (2005) "Engage Me or Enrage Me" What Today's Learners Demand. Educause Review, 40(5). Retrieved April 11, 2010, from http://net.educause.edu/ir/library/pdf/ERM0 553.pdf

16. Sendall, P., Ceccucci, W., and Peslak, A. (2008) "Web 2.0 Matters: An Analysis of Implementing Web 2.0 in the Classroom." Information Systems Education Journal, Vol. 6, No. 64. Retrieved February 2, 2008, from http://isedj.org/6/64/

17. Short, J., Williams, E., and Christie, B. (1976) The Social Psychology of Telecommunications. John Wiley \& Sons, London, 206.

18. Sweetser, K. B. (2008, February) "Teaching Tweets." Retrieved March 1, 2008, from http://www.kayesweetser.com

19. Twitter. (2010) Twitter social networking computer software. Available at http://www.twitter.com/

20. van den Broek, W. (2009, January) "Twitter and Medical Education." Retrieved January 29, 2009, from http://www.shockmd.com/2009/01/14/twitte r-andmedical-education/

21. Wankel, C. (2009) Management education using social media. Organization Management Journal, 6(4), 251-262 